\title{
PERANAN SOCIAL REPORT PADA SISTEM PERADILAN PIDANA ANAK $^{1}$
}

\author{
Elfina Lebrine Sahetapy \\ Fakultas Hukum Universitas Surabaya \\ Jl. Raya Kalirungkut Surabaya \\ elfina_69@yahoo.com
}

\begin{abstract}
The purpose of this study was to determine and assess the Social Report in performing Children Conflict With the Law cases, implementation of diversion in the settlement child cases, to find out barriers, alternatives solution, and overcoming obstacles encountered by Juvenile Probation Counselor. The Social Report's existence plays an important role in the decision making of whether or not performing the diversion. The methodology used in this study is normative juridical as the main approach. Basic considerations on implemeting Social Report is based on the general provisions in Act No.11/2012 concerning The Juvenile Criminal Justice System. Implementation of Social Report in juvenile criminal justice system is done through discussion by involving the parties concerned, namely the perpetrators, victims, families of victims/perpetrators, law enforcement agencies including Juvenile Probation Counselor.
\end{abstract}

Keywords: Social Report; Juvenile Criminal Justice System; Juvenile Probation Counselors

\begin{abstract}
Abstrak
Tujuan dari penulisan ini adalah untuk mengevaluasi dan mengkaji keberadaan Penelitian Kemasyarakatan atau yang dikenal dengan Social Report dalam kasus Anak yang Berkonflik dengan Hukum, dikaitkan dengan pelaksanaan diversi dalam penyelesaian perkara anak. Keberadaan Social Report memegang peranan yang penting dalam pengambilan keputusan apakah dilakukan diversi atau tidak. Metodologi yang digunakan adalah yuridis normatif dengan menggunakan bahan kepustakaan yang ditunjang oleh interview dari pihak-pihak yang terkait. Landasan hukum yang digunakan untuk pelaksanaan Social Report diatur di dalam UndangUndang Nomor 11 Tahun 2012 tentang Sistem Peradilan Pidana Anak. Para pihak yang juga terlibat dalam kontribusi penulisan ini adalah Anak yang Berhadapan dengan Hukum yakni pelaku dan korban beserta dengan keluarganya. Di samping itu juga dengan aparat penegak hukum dan terutama dengan Pembimbing Kemasyarakatan.
\end{abstract}

Kata Kunci: Penelitian Kemasyarakatan; Sistem Peradilan Pidana Anak; Pembimbing Kemasyarakatan

\footnotetext{
${ }^{1}$ Artikel hasil penelitian dari Hibah Penelitian Strategis Nasional Dikti No. 015/SP-Lit/LPPM-01/Ristekdikti/ $\mathrm{FH} / \mathrm{III} / 2018$.
} 


\section{A. Pendahuluan}

Pemahaman mengenai anak menjadi kunci dalam memahami perlindungan anak dengan berbagai macam mekanismenya. Ketentuan hukum yang berlaku pun menekankan pentingnya pengetahuan terkait pemahaman akan anak dan anak yang berkonflik dengan hukum. Anak dalam usianya sangat rentan terlibat dalam kejahatan baik sebagai pelaku maupun korban. Sekalipun anak terlibat dalam kejahatan, pemikiran akan perlindungan terhadap hak-hak yang dimiliki anak tetap penting untuk diberikan, secara khusus sebagai pelaku (Wahyudhi, 2015, p. 3).

Menteri Hukum dan HAM pada saat peresmian Lembaga Pembinaan Khusus Anak (selanjutnya disebut LPKA) dan Lembaga Penempatan Anak Sementara (LPAS) dalam pidatonya menyebutkan bahwa metode yang dianggap tepat dalam penanganan anak berhadapan dengan hukum dan selaras dengan jalan perubahan yang digagas oleh Bapak Presiden kita, adalah melalui pendidikan berbasis budi pekerti. Mengapa ini perlu dilakukan? Karena anak berhadapan dengan hukum memerlukan pengetahuan dan pemahaman atas nilai nilai perilaku manusia yang diukur menurut kebaikan dan keburukannya melalui ukuran norma agama, norma hukum, tata krama, dan sopan santun, norma budaya/adat istiadat masyarakat. Tidak hanya itu, adanya pendidikan budi pekerti akan mengidentifikasi perilaku positif sehingga diharapkan dapat diimplementasikan kedalam perbuatan, perkataan, pikiran, sikap, perasaan, dan kepribadian peserta didik. Sehingga diharapkan anak berkonflik hukum akan terbentuk menjadi karakter yang berbudi pekerti luhur, dapat bersikap sopan santun, tertib menurut aturan dan adat yang berlaku, serta menunjukkan tingkah laku yang beradab. Apabila nilai - nilai luhur ini dapat terinternalisasi dengan baik dan bisa menjadi karakter setiap anak bangsa, maka perwujudan bangsa Indonesia sebagai bangsa yang berbudi pekerti luhur adalah sebuah keniscayaan. Pada akhirnya bangsa Indonesia akan menjadi bangsa besar, yang keberadaannya diperhitungkan oleh bangsa bangsa lain di dunia.

Namun apa yang disampaikan di atas terkait dengan harapan agar anak yang dikenakan sanksi pidana penjara diberikan pembinaan agar dapat berubah dan menjadi pribadi yang lebih baik pada faktanya tidaklah sesederhana dan semudah itu. Ada salah satu faktor yang menjadi kendala jika anak tersebut sudah mendapatkan proses pembinaan yang baik di Lembaga Pembinaan Khusus Anak (yang selanjutnya disebut LPKA) namun pada saat anak tersebut kembali ke masyarakat ada "stigmatisasi" yang melekat sehingga tidak memudahkan anak untuk bersosialisasi. Teori "Labeling" menunjukkan bahwa pelabelan atau dengan kata lain stigmatisasi ini dapat merusak masa depan seseorang dalam hal ini anak dimana masa depannya masih panjang. Oleh sebab itu, penerapan pidana penjara pada anak haruslah merupakan suatu hal yang bersifat "ultimum remedium" atau "the last resort", yang artinya sanksi pidana penjara haruslah merupakan upaya yang paling akhir. Hal ini dipertegas oleh Aguilar bahwa "the promised rehabilitation of inmates is not achieved as developing a self-regulatory mechanism in a total institution is not possible (Aguilar, 2016, p. 156). Berdasarkan hal tersebut, hakim hendaknya mempertimbangkan setiap kondisi dan situasi yang dimiliki atau terhubung dengan anak melalui Social Report, sehingga dapat mengambil suatu putusan yang tidak melanggar hak anak khususnya asas kepentingan yang terbaik bagi anak mengingat bahwa proses pembinaan di penjara juga tidak menjanjikan perubahan perilaku pada anak.

Di sinilah peranan dari Sosial Report menjadi sangat penting. Mengapa peranan Social Report sangat penting? Beberapa topik dari isi Social Report tersebut terkait dengan rekam jejak anak yang diduga melakukan tindak pidana. Siapakah orang tuanya dan apa pekerjaan orang tuanya; dimanakah anak ini bertempat tinggal dan bersama siapa; bagaimana perilaku anak 
sehari-hari; apakah ada problem dalam rumah tangga orang tuanya; bagaimana pergaulan anak ini setiap harinya, dan masih banyak pertanyaan-pertanyaan yang dapat memperlihatkan situasi dan kondisi anak yang sesungguhnya. Dalam teori etiologi kriminal dinyatakan bahwa penyebab seseorang memiliki perilaku "evil" dikarenakan adanya sebab-sebab yang dapat menjadi faktor pemicu (pull factors) sehingga seseorang berbuat jahat. Penjatuhan sanksi pidana yang tidak tepat dapat membuat seseorang bertambah baik atau bisa terjadi bertambah jahat.

Peranan Social Report dalam proses Diversi sebagai bagian dari penerapan Restorative Justice dalam Sistem Peradilan Pidana Anak juga sangat penting. Hal ini dikarenakan, pada saat anak yang diduga melakukan tindak pidana tersebut dikenakan suatu pilihan apakah dapat diterapkan proses diversi atau tidak sesuai dengan persyaratan yang ada dalam Undang-Undang Nomor 11 Tahun 2012 tentang Sistem Peradilan Pidana Anak (yang selanjutnya disebut UU Sistem Peradilan Pidana Anak). Pemahaman konsep Restorative Justice disampaikan oleh Theo Gavrielides seperti yang dikutip oleh Mahfud Jufri yakni "Restorative Justice may refer to an alternative process for solving disputes, to alternative sanctioning options, or to a distinctively different, new model of criminal justice organized around principles of restoration to victims, offenders and the community in which they live (Jufri, Nazeri, \& Dhanapal, 2019, p. 1). Adapun Burt Galaway mendefinisikan, restorative justice: as a response to criminal behavior that seeks to restore losses suffered by crime victims and to facilitate peace and tranquility among opposing parties (Galaway \& Hudson, 2000).

Oleh sebab itu, tulisan ini mengangkat topik mengenai pentingnya peranan penelitian kemasyarakatan atau yang lebih dikenal dengan istilah Social Report, untuk dapat dan bersifat wajib menjadi bahan pertimbangan bagi setiap aparat penegak hukum di dalam memutuskan apakah kasus anak yang berkonflik dengan hukum dapat diselesaikan dengan Diversi dengan tetap mengacu pada syarat dilakukannya Diversi seperti yang sudah diatur di dalam UndangUndang Sistem Peradilan Pidana Anak.

Berdasarkan penelusuran, penelitian atau kajian tentang Social Report ini sangat sedikit. Pada tahun 2012, Kanwil Hukum dan HAM Provinsi Jawa Timur pernah melakukan penelitian terhadap keberadaan Social Report ini namun hasilnya tidak dipublikasikan. Dengan kata lain, sesungguhnya peran dari Pembimbing Kemasyarakatan dalam hal pembuatan "laporan penelitian kemasyarakatan" dan yang selanjutnya akan disebut dengan Social Report, bagi anak nakal menduduki peran yang penting dalam upaya untuk menghindarkan pemidanaan terhadap anak. Suatu sistem peradilan anak menjadi bergantung sesungguhnya pada peran dari Pembimbing Kemasyarakatan tersebut.

Penulisan ini dimaksudkan untuk mengembalikan kedudukan Penelitian Kemasyarakatan atau yang disebut dengan Social Report ini sebagai suatu alat informasi yang sangat penting dan dibutuhkan oleh aparat penegak hukum di dalam mempertimbangkan putusan yang tepat untuk anak serta melindungi hak anak meski anak tersebut sedang terlibat suatu masalah kejahatan.

\section{B. Metode Penelitian}

Metodologi yang digunakan adalah yuridis normatif dengan menggunakan bahan kepustakaan yang ditunjang oleh interview dari pihak-pihak yang terkait. Penelitian hukum ini menggunakan data primer dengan mendatangi secara langsung Balai Pemasyarakatan dan Lembaga Pemasyarakatan di Jawa Timur, serta beberapa anak didik pemasyarakatan sebagai sampling. Pada hakikatnya inti permasalahan hukumnya berangkat dari ketentuan yang ada di dalam ketentuan hukum yang ada terkait masalah kenakalan anak, yang didahului dengan instrumeninstrumen internasional terkait dengan penanganan delinkuensi anak. Data yang diperlukan diperoleh melalui teknik 
wawancara dengan sistem open questionairre dan juga close questionairre kepada key informan.

\section{Hasil dan Pembahasan}

\section{Ruang Lingkup Peradilan Pidana Anak}

Pada akhirnya Indonesia membuat suatu undang-undang baru, yakni Undang-Undang No. 11 Tahun 2012 tentang Sistem Peradilan Anak di Indonesia yang diberlakukan mulai Juni 2014. Ada hal-hal yang baru diatur dan diharapkan dapat memberikan perlindungan terhadap hak-hak anak yang berkonflik dengan hukum, di antaranya: a) Masa penahanan jangka waktunya paling lama 7 hari; b) Jika tidak terdapat Lapas Anak, maka mereka akan ditempatkan di Lembaga Penempatan Anak Sementara; c) Dibentuknya polisi, jaksa dan hakim anak, sehingga mereka qualifed secara pengetahuan tentang kondisi dan sifat khusus anak; d) Yang terpenting adalah dicantumkannya diversi sebagai pidana alternatif yang bertujuan untuk: mencapai perdamaian antara korban dan anak, menyelesaikan perkara di luar proses peradilan, sehingga tidak menimbulkan trauma dan stigma pada anak, menghindarkan anak dari perampasan kemerdekaan, dan memberikan sanksi yang menitikberatkan pada unsur pendidikan. Undang - Undang Nomor 11 Tahun 2012 tentang Sistem Peradilan Pidana Anak mengamanatkan dalam hal penanganan ABH berpedoman pada asas - asas yang melekat pada anak, di antaranya: 1) perlindungan; 2) keadilan; 3) kepentingan terbaik bagi anak; 4) penghargaan terhadap pendapat anak; dan penghindaran pembalasan dalam penyelesaian perkara anak. Oleh karena itu, sangat penting bagi kita untuk memahami asas - asas tersebut sebagai wujud transformasi perlakuan $\mathrm{ABH}$ di Indonesia yang sekaligus hal ini menjadi tonggak sejarah dalam perubahan sistem perlakuan terhadap anak yang berhadapan dengan hukum.
Pola pembinaan di Indonesia diatur di dalam UU No. 12 Tahun 1995 tentang Pemasyarakatan, bertujuan untuk: a) Meningkatkan kualitas ketakwaan kepada Tuhan yang Maha Esa; b) Memperbaiki intelektual, sikap dan perilaku; c) Menjaga kesehatan jasmani dan rohani. Melalui pemasyarakatan ini diharapkan anak didik pemasyarakatan akan menyadari kesalahan, memperbaiki diri dan tidak mengulangi tindak pidana, dan diterima oleh masyarakat serta dapat berperan aktif dalam pembangunan dan dapat hidup wajar sebagai warga masyarakat yang baik dan berguna serta bertanggung jawab. Namun tujuan ini sulit untuk dipenuhi karena adanya kendala yang memerlukan perhatian yang cukup serius. Ini adalah keadaan yang memprihatinkan dan tidak memberikan perlindungan terhadap hak dari seseorang yang di bawah umur yang terbukti melakukan suatu perbuatan pidana. Penyebutan terhadap mereka dalam UU Sistem Peradilan Pidana Anak adalah Anak yang Berkonflik dengan Hukum.

Saat ini, hanya ada 18 Lembaga Pemasyarakatan (Lapas) Anak di Indonesia dari 34 provinsi di Indonesia, yakni: Lapas anak Medan-Sumatera Utara, Tanjung PatiSumatera Barat, Palembang-Sumatera Selatan, Pekanbaru-Riau, Muara BulianJambi, Bandar Lampung-Lampung, Lapas anak Pria Tangerang-Banten, Lapas anak wanita Tangerang-Banten, Bandung-Jawa Barat, Kutoarjo-Jawa Tengah, Blitar-Jawa Timur, Gianyar-Bali, Mataram-Nusa Tenggara Barat, Kupang-Nusa Tenggara Timur, Parepare-Sulawesi Selatan, Tomohon-Sulawesi Utara, PontianakKalimantan Barat dan MartapuraKalimantan Selatan. Dapat dibayangkan bahwa pada provinsi yang tidak memiliki lembaga pemasyarakatan anak, para terpidana anak dan anak tahanan akan menempati penjara yang sama dengan orang dewasa. Karena alasan jarak tempuh yang jauh antara satu provinsi dengan provinsi lain, dan juga karena adanya keterbatasan biaya, maka di beberapa daerah ada yang memisahkan sel dewasa dan anak, namun 
ada juga yang menyatukan mereka dalam sel yang sama dengan alasan tidak adanya sarana dan fasilitas di daerah tersebut. Hal ini tentu membawa dampak yang sangat buruk pada anak, karena mereka dapat mengalami kekerasan baik fisik, psikis maupun seksual.

Jumlah tahanan anak dan terpidana anak, perincian dari Kementerian Hukum dan HAM melalui data Kemenkumham mencatat jumlah seluruh tahanan anak dan anak pidana di seluruh Indonesia berjumlah 5.709 dengan rincian ada tahanan anak 2.197 orang (2.133 orang laki-laki dan 64 orang perempuan) ditambah anak pidana berjumlah 3.512 orang (3.444 orang lakilaki dan 68 orang perempuan). Lembaga Pemasyarakatan (Lapas) Anak hanya menampung 28 persen Anak Berhadapan dengan Hukum (ABH) yang terdiri atas 2.197 tahanan anak dan 3.512 anak pidana dengan jumlah total 5.709 anak. Kemampuan daya tampung Lembaga Pembinaan Khusus Anak yang ada di setiap provinsi cukup memprihatinkan dan tidak sebanding dengan jumlah terpidana anak yang ada. Fakta ini menunjukkan bahwa kapasitas Lembaga Pembinaan Khusus Anak yang ada sangat kurang sedangkan data lain menunjukkan adanya peningkatan tingkat kenakalan anak yang cukup signifikan. Data dari KPAI menunjukkan setiap tahun 6000 anak di Indonesia berkonflik dengan hukum. Dari jumlah tersebut 3800 anak berakhir di Lembaga Pemasyarakatan Anak, dan sisanya ditahan di Lapas dewasa atau di tahanan kepolisian yang sebetulnya tidak layak bagi Anak.

\section{Diversi Wujud Keadilan Restoratif}

$\begin{array}{crrr}\text { Sistem hukum } & \text { pidana } & \text { Indonesia } \\ \text { memasuki } & \text { babak } & \text { baru } & \text { dalam }\end{array}$
perkembangannya. Salah satu bentuk pembaharuan yang ada dalam hukum pidana Indonesia adalah pengaturan tentang hukum pidana dalam perspektif dan pencapaian keadilan kepada perbaikan maupun pemulihan keadaan setelah peristiwa dan proses peradilan pidana yang dikenal dengan keadilan restoratif (restoratif justice) yang berbeda dengan keadilan retributif (menekankan keadilan pada pembalasan) dan keadilan restitutif (menekankan keadilan pada ganti rugi) (Mansyur, 2017).

Keadilan restoratif ini diartikan oleh Tony F. Marshall, sebagai suatu proses dimana semua pihak yang berhubungan dengan tindak pidana tertentu bersama-sama memecahkan masalahnya dan bagaimana menangani akibatnya di masa yang akan datang atau implikasinya di masa depan (Marshall, 1999). John Braithwaite menegaskan bahwa restorative justice has been the dominant model of criminal justice throughout most of human history for perhaps all the world's people (Braithwaite, 2002). Perlu untuk diketahui bahwa teori dari Braithwaite terkait "shaming" harus dibedakan dengan "stigmatisasi", karena konsep Restorative Justice yang menghadirkan banyak pihak dalam penyelesaian kasus anak di luar pengadilan sangat rentan terhadap pelabelan oleh masyarakat. Wilson mengungkapkan terkait hal tersebut dalam pernyataan bahwa "an important distinction for Braithwaite's theory is that shaming must be reintegrative as opposed to stigmatizing. Reintegrative shaming is considered to be an integrated theory, borrowing from labeling, subcultural, control, opportunity and social learning theories of crime (Wilson, Olaghere, \& Kimbrell, 2017, p. 14).

Konsep penggunaan diversi menurut Wikan Sinatrio dalam penerapan sanksi dilakukan sebagai upaya penanganan anak yang berkonflik dengan hukum ini untuk penghindaran proses peradilan pada anak pelaku tindak pidana. Diversi dalam Undang-Undang No 11 Tahun 2012 tentang Sistem Peradilan Pidana Anak sebagai subtansi yang paling yang dimaksudkan untuk menghindari dan menjauhkan anak dari proses peradilan sehingga dapat menghindari stigmatisasi terhadap anak yang berhadapan dengan hukum. Pengaturan diversi dalam Undang-Undang No. 11 Tahun 2012 tentang Sistem Peradilan Pidana Anak ini telah dipertegas oleh Mahkamah Agung dengan dikeluarkannya Peraturan 
Mahkamah Agung (PERMA) Nomor 4 Tahun 2014 tentang Pedoman Pelaksanaan Diversi dalam Sistem Peradilan Pidana Anak. Diversi ini dilakukan sebagai pengalihan penyelesaian perkara anak dari proses peradilan pidana ke proses di luar peradilan pidana. Pelaksanaan diversi dilakukan sejak mulai dari penyidikan sampai dengan persidangan. Diversi dapat dilakukan terhadap tindak pidana yang diancam dengan pidana penjara di bawah 7 (tujuh) tahun; dan bukan merupakan pengulangan tindak pidana (Aji, 2019, p. 80). Penerapan diversi tersebut dimaksudkan untuk mengurangi dampak negatif keterlibatan anak dalam suatu proses peradilan.

Substansi yang paling mendasar dalam Undang-Undang No. 11 Tahun 2012 tentang Sistem Peradilan Pidana Anak ini, adalah pengaturan secara tegas mengenai Keadilan Restoratif dan Diversi yang dimaksudkan untuk menghindari dan menjauhkan Anak dari proses peradilan sehingga dapat menghindari stigmatisasi terhadap Anak yang berhadapan dengan hukum dan diharapkan Anak dapat kembali ke dalam lingkungan sosial secara wajar (Sosiawan, 2016). Oleh karena itu, sangat diperlukan peran serta semua pihak dalam rangka mewujudkan hal tersebut. Proses itu harus bertujuan pada terciptanya Keadilan Restoratif, baik bagi Anak maupun bagi korban. Keadilan Restoratif merupakan suatu proses diversi, yaitu semua pihak yang terlibat dalam suatu tindak pidana tertentu bersama-sama mengatasi masalah serta menciptakan suatu kewajiban untuk membuat segala sesuatunya menjadi lebih baik dengan melibatkan korban, anak, dan masyarakat dalam mencari solusi untuk memperbaiki, rekonsiliasi, dan menenteramkan hati yang tidak berdasarkan pembalasan.

Pengertian Keadilan Restoratif yang dirumuskan dalam Undang-Undang Sistem Peradilan Pidana Anak didefinisikan sebagai penyelesaian perkara tindak pidana dengan melibatkan pelaku, korban, keluarga pelaku/korban, dan pihak lain yang terkait untuk bersama-sama mencari penyelesaian yang adil dengan menekankan pemulihan kembali pada keadaan semula, dan bukan pembalasan (Hambali, 2019). Sedangkan diversi adalah pengalihan penyelesaian perkara Anak dari proses peradilan pidana ke proses di luar peradilan pidana. Diversi sebagai proses penanganan anak yang bermasalah dengan hukum. Penanganan anak melalui diversi, dengan tujuan agar anak yang bemasalah dengan hukum tidak secara langsung ditangani melalui peradilan secara prosedural formal. Hal tersebut agar anak yang bermasalah dengan hukum terhindar dari dampak negatif sistem peradilan pidana.

Konsep diversi ini sebenarnya diadopsi dari ketentuan Standard Minimum Rules for The Administration of Juvenile Justice atau dikenal dengan nama The Beijing Rules, yang merupakan aturan dasar aturan pokok yang harus dipenuhi dalam sistem peradilan pidana anak. Berdasarkan Rule 11.1, 11.2 dan Rule 17.4. United Nation Standard Minimum Rules for the Administration of Juvenile Justice (The Beijing Rules), diversi (diversion) adalah pemberian kewenangan kepada aparat hukum untuk mengambil tindakan-tindakan kebijaksanaan dalam menangani atau menyelesaikan masalah pelanggar anak dengan tidak mengambil jalan formal antara lain menghentikan atau tidak meneruskan/melepaskan dari proses peradilan pidana atau mengembalikan/menyerahkan kepada mayarakat dan bentuk-bentuk kegiatan pelayanan sosial lainnya.

Ada perbedaan pemahaman mengenai diversi sesuai dengan penerapan di masingmasing wilayah. Menurut Jack E.Bynum, definisi diversi adalah: Diversion is "an attempt to divert, or channel out, youthful offenders from the juvenile justice system". Jika diterjemahkan secara bebas mengandung pengertian bahwa diversi adalah sebuah tindakan atau perlakuan untuk mengalihkan atau menempatkan pelaku tindak pidana anak keluar dari sistem peradilan pidana (Thompson \& Bynum, 2002). 
Penerapan diversi dapat dilakukan di dalam semua tingkatan pemeriksaan, dimaksudkan untuk mengurangi dampak negatif keterlibatan anak dalam proses peradilan tersebut (Arief, 1998). Prinsip utama pelaksanaan konsep diversi yaitu tindakan pendekatan dan pemberian kesempatan pada pelaku untuk berubah. Petugas harus menunjukkan pentingnya ketaatan kepada hukum dengan cara pendekatan persuasif dan menghindarkan penangkapan dengan menggunakan tindakan kekerasan dan pemaksaan untuk melaksanakan diversi. Penggunaan kekerasan akan membawa kepada sifat keterpaksaan sebagai hasil dari penegakan hukum. Diversi sebagai usaha mengajak masyarakat untuk taat dan menegakkan hukum dengan tetap mempertimbangkan rasa keadilan sebagai prioritas utama di samping pemberian kesempatan kepada pelaku memperbaiki diri. Diversi tidak bertujuan mengabaikan hukum dan keadilan, akan tetapi diversi merupakan cara baru menengakkan keadilan dalam masyarakat (Sepud, 2013).

\section{Peranan Social Report di Sistem Peradilan Pidana Anak}

Masalah yang cukup signifikan dalam proses persidangan yang berlaku saat ini adalah terkait dengan Penelitian Kemasyarakatan yang biasa disebut dengan istilah Social Report. Keberadaaan Social Report ini sangat penting, karena latar belakang anak sampai terjadinya tindak pidana tersebut harus disusun secara terinci, sehingga Social Report ini diharapkan dapat menjadi pegangan bagi pertimbangan hakim dalam memutuskan perkara tersebut. Bynum and Thompson menyatakan (diterjemahkan secara bebas) bahwa untuk mengatasi persoalan besar terkait delinkuensi dan persoalan kejahatan yang dilakukan oleh seseorang di bawah umur, diperlukan suatu metoda dimana semua informasi penyebab mengapa kejahatan itu terjadi dapat diketahui (Thompson \& Bynum, 2002, p. 24). Namun dalam kenyataannya, tidak semua kasus anak yang melalui proses hukum dimulai dari penyelidikan, penyidikan sampai disidangkan memiliki Social Report (hasil penelitian di tahun 2012).

Kementerian Hukum dan Hak Asasi Manusia (HAM) Republik Indonesia merupakan lembaga pemerintahan yang berorientasi dalam bidang penegakan Hukum dan HAM di Indonesia, salah satunya yaitu Balai Pemasyarakatan (selanjutnya disebut Bapas). Bapas sebagaimana dimaksud dalam Pasal 1 angka 4 Undang-Undang No. 12 Tahun 1995 tentang Pemasyarakatan, adalah pranata untuk melaksanakan bimbingan Klien Pemasyarakatan. BAPAS merupakan ujung tombak dari Pemasyarakatan, yang berfungsi pada proses peradilan sejak tahap pra adjudikasi, adjudikasi, dan post adjudikasi. Sebagai ujung tombak sudah seharusnya fungsi BAPAS saat sekarang ini perlu disertai dengan penegasan implementasinya di dalam sistem pemasyarakatan maupun dalam sistem peradilan pidana. Namun demikian keberadaan dan peran BAPAS tersebut sering diabaikan atau bahkan tidak diketahui oleh subsistem yang lain dalam sistem peradilan pidana. Keadaan pengabaian atau tidak diketahuinya Balai Pemasyarakatan (BAPAS) tersebut tentu akan mempengaruhi keberhasilan kegiatan sistem peradilan pidana secara keseluruhan. BAPAS merupakan bagian yang tak terpisahkan dari Sistem Tata Peradilan, mempunyai tugas melaksanakan pembimbing dan mendampingi anak didik pemasyarakatan dalam proses peradilan anak.

Seluruh instrumen hukum dan kebijakan baik yang bersifat internasional maupun nasional haruslah diupayakan guna melindungi kepentingan anak, dan untuk itu harus ada mekanisme-mekanisme khusus yang diciptakan demi pencapaian tujuannya. UN Standard Minimum Rules for the Administration of Juvenile Justice merupakan prinsip yang dipegang dalam rangka menciptakan sistem peradilan anak, khususnya pada Rule 17 menetapkan mengenai laporan penyelidikan sosial 
(social inquiry report). Perihal pembuatan laporan tersebut, UU No. 11 Tahun 2012 menetapkan bahwa yang berwenang membuat adalah petugas pembimbing kemasyarakatan.

Berdasarkan Pasal 1 angka 24 jo Pasal 65 UU No. 11 Tahun 2012, bahwa Pembimbing kemasyarakatan memiliki 5 (lima) tugas utama. Pertama, bertugas membuat laporan penelitian kemasyarakatan untuk kepentingan Diversi, melakukan pendampingan, pembimbingan, dan pengawasan terhadap Anak selama proses diversi dan pelaksanaan kesepakatan, termasuk melaporkannya kepada pengadilan apabila diversi tidak dilaksanakan. Kedua, membuat laporan penelitian kemasyarakatan untuk kepentingan penyidikan, penuntutan, dan persidangan dalam perkara anak, baik di dalam maupun di luar sidang, termasuk di dalam LPAS dan LPKA. Ketiga, menentukan program perawatan anak di LPAS dan pembinaan Anak di LPKA bersama dengan petugas pemasyarakatan lainnya. Keempat, melakukan pendampingan, pembimbingan, dan pengawasan terhadap anak yang berdasarkan putusan pengadilan dijatuhi pidana atau dikenai tindakan. Kelima, melakukan pendampingan, pembimbingan, dan pengawasan terhadap anak yang memperoleh asimilasi, pembebasan bersyarat, cuti menjelang bebas, dan cuti bersyarat.

Manfaat dari laporan hasil penelitian kemasyarakatan tersebut sebagai salah satu bahan pertimbangan Hakim dalam memutuskan perkara anak. Hakim wajib mempertimbangkan laporan penelitian kemasyarakatan tersebut karena dalam menentukan sanksi yang akan dijatuhkan kepada anak yang berkonflik dengan hukum. Hakim mempunyai pilihan antara lain menerapkan diversi jika memenuhi syarat penjatuhan diversi atau menjatuhkan sanksi dan/atau mengambil tindakan. Secara teoritis pilihan-pilihan sanksi yang dapat dijatuhkan kepada anak adalah untuk mengambil keputusan yang terbaik untuk anak. Anak yang berkonflik dengan hukum secara sosiologis tidak dapat dinyatakan salah sendiri karena anak tersebut belum menyadari akibat dari tindakannya dan belum dapat memilih mana tindakan yang baik dan mana tindakan yang tidak baik bagi dirinya maupun bagi orang lain.

Sehubungan dengan Laporan Penelitian Kemasyarakatan (Social Report) menurut Kristianto selaku Kepala Lembaga Pembinaan Khusus Anak Blitar, bahwa BAPAS di dalam fungsinya membuat Social Report dan berkewajiban untuk mendampingi anak di dalam proses persidangan tetapi jika hakim sudah menjatuhkan putusan terhadap anak tersebut, maka BAPAS tidak lagi melakukan pendampingan lalu kewenangan itu diserahkan kepada Lembaga Pembinaan Khusus Anak.

\section{Simpulan}

Di akhir penulisan ini, penulis dapat menyampaikan simpulan bahwa untuk mewujudkan suatu sistem peradilan anak yang bersifat restoratif haruslah dibarengi dengan berbagai upaya pengusahaan sistem pemantauan dan penelitian terhadap anak, sebelum anak tersebut mendapatkan putusan pengadilan. Undang-undang tidak mengatur jelas dan detail mengenai Laporan Penelitian Kemasyarakatan tersebut. BAPAS memegang peranan penting untuk mengetahui latar belakang dan perbuatan anak-anak sampai anak melakukan pelanggaran hukum. Hal tersebut dikarenakan dalam penyelesaikan perkara Anak yang Berkonflik dengan Hukum, Hakim wajib mempertimbangkan Laporan Penelitian Kemasyarakatan mengenai latar belakang anak maupun keluarga dan anak yang bersangkutan.

Saran yang dapat penulis sampaikan dalam akhir tulisan ini adalah seharusnya Undang-Undang menetapkan bahwa Social Report bersifat imperatif. Dengan kata lain, Social Report bersifat wajib untuk dilakukan BAPAS dalam mendampingi anak yang berkonflik dengan hukum pada proses peradilan pidana. 


\section{DAFTAR PUSTAKA}

Aguilar, M. V. G. (2016). Instilling Values to Children in Conflict with the Law in a Youth Facility. Journal of Human Values, 22(3), 155-164.

Aji, W. S. (2019). The Implementation of Diversion and Restorative Justice in the Juvenile Criminal Justice System in Indonesia. Journal of Indonesia Legal Studies, 4(1), 73-88.

Arief, B. N. (1998). Beberapa Aspek Kebijakan Penegakan dan Pengembangan Hukum Pidana. Bandung: Citra Aditya Bakti.

Braithwaite, J. (2002). Restorative Justice And Rsponsive Regulation. New York: Oxford University Press.

Galaway, B., \& Hudson, J. (2000). Restorative Justice: International Perspective. USA: Criminal Justice Press.

Hambali, A. R. (2019). Penerapan Diversi terhadap Anak yang Berhadapan dengan Hukum dalam Sistem Peradilan Pidana. Jurnal Ilmiah Kebijakan Hukum, 13(1), $15-30$

Jufri, M., Nazeri, N. M., \& Dhanapal, S. (2019). Restorative Justice: an Alternative Process for Solving Juvenile Crimes in Indonesia. Brawijaya Law Journal: Journal of Legal Studies, 6(2), 157-169.
Mansyur, R. (2017). Keadilan Restoratif Sebagai Tujuan Pelaksanaan Diversi Pada Sistem Peradilan Pidana Anak. Retrieved July 9, 2020, from https://www.mahkamahagung.go.id/id/a rtikel/2613/keadilan-restoratif-sebagaitujuan-pelaksanaan-diversi-pada-sistemperadilan-pidana-anak

Marshall, T. F. (1999). Restorative Justice: An Overview. London: Home Office.

Sepud, I. M. (2013). Perlindungan Hukum Terhadap Anak Yang Berhadapan Dengan Hukum Melalui Diversi Dalam Sistem Peradilan Pidana Anak. Surabaya: RA. De Rozarie.

Sosiawan, U. M. (2016). Perspektif Restorative Justice Sebagai Wujud Perlindungan Anak Yang Berhadapan Dengan Hukum. Jurnal Penelitian Hukum De Jure, 16(4), 425-438.

Thompson, W. E., \& Bynum, J. E. (2002). Juvenile Delinquency: a Sociological Approach (5th ed.). Boston: A Pearson Education Company.

Wahyudhi, D. (2015). Perlindungan Terhadap Anak Yang Berhadapan Dengan Hukum Melalui Pendekatan Restorative Justice. Jurnal Ilmu Hukum Jambi, 6(1), 143-163.

Wilson, D. B., Olaghere, A., \& Kimbrell, C. S. (2017). Effectiveness of Restorative Justice Principles in Juvenile Justice : A Meta Analysis. United States of America. 